University of Nebraska - Lincoln

DigitalCommons@University of Nebraska - Lincoln

January 2008

\title{
Loss of housekeeping selenoprotein expression in mouse liver modulates lipoprotein metabolism
}

\author{
Aniruddha Sengupta \\ National Institutes of Health, Bethesda, MD \\ Bradley A. Carlson \\ National Institutes of Health, Bethesda, MD \\ Victoria J. Hoffmann \\ National Institutes of Health, Bethesda, MD \\ Vadim N. Gladyshev \\ University of Nebraska-Lincoln, vgladyshev@rics.bwh.harvard.edu \\ Dolph L. Hatfield \\ National Institutes of Health, Bethesda, MD
}

Follow this and additional works at: https://digitalcommons.unl.edu/biochemgladyshev

Part of the Biochemistry, Biophysics, and Structural Biology Commons

Sengupta, Aniruddha; Carlson, Bradley A.; Hoffmann, Victoria J.; Gladyshev, Vadim N.; and Hatfield, Dolph L., "Loss of housekeeping selenoprotein expression in mouse liver modulates lipoprotein metabolism" (2008). Vadim Gladyshev Publications. 73.

https://digitalcommons.unl.edu/biochemgladyshev/73

This Article is brought to you for free and open access by the Biochemistry, Department of at DigitalCommons@University of Nebraska - Lincoln. It has been accepted for inclusion in Vadim Gladyshev Publications by an authorized administrator of DigitalCommons@University of Nebraska - Lincoln. 


\title{
Loss of housekeeping selenoprotein expression in mouse liver modulates lipoprotein metabolism
}

\author{
Aniruddha Sengupta ${ }^{\text {a }}$, Bradley A. Carlson ${ }^{\text {a }}$, Victoria J. Hoffmann ${ }^{\text {b }}$, \\ Vadim N. Gladyshev ${ }^{c}$, Dolph L. Hatfield ${ }^{\mathrm{a}, *}$ \\ a Molecular Biology of Selenium Section, Laboratory of Cancer Prevention, Center for Cancer Research, National Cancer Institute, \\ National Institutes of Health, Bethesda, MD 20892, USA \\ ${ }^{\mathrm{b}}$ Office of the Director, Diagnostic and Research Services Branch, National Institutes of Health, Bethesda, MD 20892, USA \\ ${ }^{\mathrm{c}}$ Department of Biochemistry, University of Nebraska, Lincoln, NE 68588, USA
}

Received 25 October 2007

Available online 26 November 2007

\begin{abstract}
Selenium is incorporated into proteins as selenocysteine $(\mathrm{Sec})$, which is dependent on its specific tRNA, designated tRNA ${ }^{[\mathrm{Ser}] \mathrm{Sec}}$. Targeted removal of the tRNA ${ }^{[\mathrm{Ser}] \mathrm{Sec}}$ gene (Trsp) in mouse hepatocytes previously demonstrated the importance of selenoproteins in liver function. Herein, analysis of plasma proteins in this Trsp knockout mouse revealed increases in apolipoprotein E (ApoE) that was accompanied by elevated plasma cholesterol levels. The expression of genes involved in cholesterol biosynthesis, metabolism and transport were also altered in knockout mice. Additionally, in two transgenic Trsp mutant mouse lines (wherein only housekeeping selenoprotein synthesis was restored), the expression of $A p o E$, as well as genes involved in cholesterol biosynthesis, metabolism and transport were similar to those observed in wild type mice. These data correlate with reports that selenium deficiency results in increased levels of ApoE, indicating for the first time that housekeeping selenoproteins have a role in regulating lipoprotein biosynthesis and metabolism. (C) 2007 Elsevier Inc. All rights reserved.
\end{abstract}

Keywords: Apolipoprotein E; Conditional-knockout; Selenocysteine tRNA; Housekeeping selenoproteins; Stress-related selenoproteins

The importance of trace elements in human health can be assessed by the fact that their reduction in the diet may lead to various disorders. One important dietary trace element is selenium, which has potent cancer chemo-preventive properties [1]. It also has protective roles against viral infection [2], cardiovascular and muscular disorders along with roles in mammalian development, male reproduction and immune function [3]. Selenium is incorporated into a select group of proteins, selenoproteins, in the form of the amino acid, selenocysteine (Sec). The biological function of selenium is thought to be exerted primarily by these proteins [4]. Of the 24 and 25 selenoproteins iden-

Abbreviations: ApoE, apolipoprotein E; Sec, selenocysteine; TBS, tris-buffered saline; Trsp, selenocysteine tRNA gene.

* Corresponding author. Fax: +1 3014354957.

E-mail address: hatfield@mail.nih.gov (D.L. Hatfield). tified in mice and humans, respectively [5], several are known to have roles in cellular redox regulation (e.g., methionine sulfoxide reductase B1 (Msrb1), glutathione peroxidases (Gpxs), and thioredoxin reductases (TRs)) [6]. Selenoprotein synthesis is dependent on the unique tRNA, designated tRNA ${ }^{[\mathrm{Ser}] \mathrm{Sec}}[4]$ which is modified posttranscriptionally for proper functioning [7]. Two bases and one nucleoside modification occur within the anticodon loop of tRNA ${ }^{[\mathrm{Ser}] \mathrm{Sec}}$ : A37 is modified to $N^{6}$-isopentenyladenosine $\left(\mathrm{i}^{6} \mathrm{~A}\right)$ and $\mathrm{U} 34$ is modified to methylcarboxyl-5'-methyluridine $\left(\mathrm{mcm}^{5} \mathrm{U}\right) ; \mathrm{mcm}^{5} \mathrm{U}$ is further modified on its ribosyl moiety to Um34 [8]. Interestingly, the synthesis of $\mathrm{Um} 34$ on $\mathrm{tRNA}{ }^{[\mathrm{Ser}] \mathrm{Sec}}$ is responsive to selenium status [9].

Removing the gene for tRNA ${ }^{[\mathrm{Ser}] \mathrm{Sec}}$ (designated Trsp) causes complete loss of selenoprotein expression and $\Delta T r s p$ is embryonic lethal $[10,11]$. In addition, we generated 
transgenic mice in which $\Delta \operatorname{Tr} s p$ mice were rescued with a mutant $\operatorname{Tr} s p$ transgene lacking $\mathrm{i}^{6} \mathrm{~A}$ at position 37 (generated by an $\mathrm{A} 37 \rightarrow \mathrm{G} 37$ mutation and the resulting transgenic mouse was designed as G37) [12] or $\mathrm{mcm}^{5} \mathrm{U}$ at position 34 (generated by an T34 $\rightarrow$ A34 mutation and the resulting transgenic mouse was designed as A34) in the Sec tRNA ${ }^{[\mathrm{Ser}] \mathrm{Sec}}$ transgene product [13]. Interestingly, housekeeping, but not stress-related selenoproteins are synthesized by A34 and G37 Sec tRNAs ${ }^{[\mathrm{Ser}] \mathrm{Sec}}$ that are transcribed and modified from the corresponding A34 and G37 transgenes [12].

We have also selectively removed Trsp in hepatocytes using loxP-Cre technology which demonstrated that proper liver function is dependent on selenoprotein expression [14]. The mean life span of the hepatocyte $\Delta \operatorname{Trsp}$ knockout mice was significantly reduced compared with their wild type counterparts [14]. These mice died suddenly as a result of hepatocellular degeneration/necrosis. Most hepatocytes had vacuolated cytoplasm and mineralization with a majority of them being apoptotic. In contrast, the liver of mice carrying $A 34$ or $G 37$ transgenes appeared to be normal, with their lifespan being similar to that of the corresponding phenotypically normal litter mates (designated herein as wild type).

In the present study, we examined the plasma protein profile of hepatocyte $\Delta T r s p$ and the corresponding wild type mice and observed an elevation in the level of a protein, later identified as apolipoprotein E (ApoE). The elevated level of ApoE was accompanied by an increase in plasma cholesterol levels in hepatocyte $\Delta \operatorname{Tr} s p$ mice. A comparative gene expression analysis of hepatocyte $\Delta T r s p$ and wild type mice revealed an enhanced expression of genes involved in cholesterol biosynthesis and a decreased expression of genes involved in cholesterol metabolism or transport. Thus, the increase in plasma cholesterol levels accompanied by alteration of genes involved in cholesterol biosynthesis in the hepatocyte $\Delta \operatorname{Trsp}$ mice reflects a link between selenoproteins and cholesterol biosynthesis. Interestingly, the levels of ApoE and cholesterol in the $A 34$ and $G 37$ transgenic and wild type mice were similar, as demonstrated by immunodetection and plasma lipid analysis, respectively. Since $A 34$ and $G 37$ transgenes restore housekeeping, but not stress-related selenoprotein synthesis, the data suggest a relationship between selenoproteins and lipoproteins, wherein housekeeping selenoproteins affect lipoprotein biosynthesis and metabolism.

\section{Materials and methods}

Materials. NuPage polyacrylamide gels, polyvinylidene difluoride membranes, Trizol reagent, and Superscript II reverse transcriptase were purchased from Invitrogen (Carlsbad, CA, USA). SuperSignal West Dura substrate was obtained from Pierce (Rockford, IL, USA); goat polyclonal antibodies against ApoE and bovine anti-goat horseradish peroxidaseconjugated secondary antibodies were obtained from Santa Cruz Biotechnology, Inc. (Santa Cruz, CA, USA). Fairplay ${ }^{\circledR}$ II Microarray Labeling kit was obtained from Stratagene (La Jolla, CA, USA), RNA Storage Solution from Ambion Inc. (Austin, TX, USA), MinElute column from Qiagen (Valencia, CA, USA) and SYBR green supermix from Bio Rad Laboratories (Hercules, CA, USA). All other reagents were commercially available products of the highest grade.

Mice and their genotyping. Control mice (genotype $\mathrm{TrSp}^{+/+}-\mathrm{AlbCr} \mathrm{CH}^{+/+}$, designated wild type), liver $\Delta \operatorname{Tr} s p$ knockout mice (genotype $\operatorname{Tr} s p^{f l f l}$-Alb$\mathrm{Cr}^{+/+}$, designated $\Delta \operatorname{Tr} s p$ ) and the $A 34$ and $G 37$ mutant Trsp transgenic mice (designated $A 34$ and $G 37$ mice and described above) were obtained as given [14]. Mice were either siblings or of similar ages, ranging between 8 and 9 weeks. The care of mice was in accordance with the National Institutes of Health institutional guidelines under the expert direction of Dr. Kyle Stump (NCI, National Institutes of Health, Bethesda, MD, USA). DNA was extracted from mouse tail clippings and genotyped by PCR with appropriate primers described earlier [14].

Microsequencing of protein. Plasma proteins were subjected to $10 \%$ SDS/PAGE and visualized by Coomassie blue staining. The elevated protein band observed on gels in plasma from $\Delta T r s p$ mice was excised, digested with trypsin, and subjected to ESI-MS/MS analysis at the mass spectrometry core facility, Redox Biology Center, University of Nebraska. The resulting spectra were analyzed against mouse protein database and expressed sequence tag databases.

Analysis of plasma lipids and western blotting. The analysis of plasma lipids was carried out at the Diagnostic and Research Services Branch and Department of Laboratory Medicine, National Institutes of Health, Bethesda, MD, USA. Plasma samples from wild type, $\Delta \operatorname{Tr} s p, A 34$, and G37 mice were electrophoresed on $10 \%$ polyacrylamide gels, transferred to polyvinylidene difluoride membranes and immunoblotted with antibodies against ApoE (1:1000 dilution). Following washes with TBST (Tween supplemented TBS), the membrane was incubated with bovine anti-goat horseradish peroxidase-conjugated secondary antibodies $(1: 20,000)$ and then washed with $0.1 \%$ TBST, incubated in SuperSignal West Dura substrate and exposed to X-ray film.

Sample preparation for microarray analysis. Total RNA from the liver of wild type, $\Delta T r s p$, A34, and $G 37$ mice was isolated using Trizol reagent according to manufacturer's protocol and dissolved in the RNA Storage Solution. To generate cDNA, $10 \mu \mathrm{g}$ RNA was incubated with $1 \mu \mathrm{l}$ oligo $\mathrm{dT}$ at $70{ }^{\circ} \mathrm{C}$ for $5 \mathrm{~min}$ and cooled on ice for $1 \mathrm{~min}$. In a separate tube, $2 \mu \mathrm{l}$ of $10 \times$ StrataScript reaction buffer, $1 \mu \mathrm{l}$ of $0.1 \mathrm{M}$ dithiothreitol, $1.0 \mu \mathrm{l}$ of $20 \times$ aminoallyl dioxy-ribonucleotide triphosphate, $0.5 \mu \mathrm{l}$ of $40 \mathrm{U} / \mu \mathrm{l}$ RNAase inhibitor and $2 \mu \mathrm{l}$ of $400 \mathrm{U} / \mu \mathrm{l}$ StrataScriptII reverse transcriptase were mixed. This mixture was added to the RNA and oligo dT mix and reverse transcription was carried out at $48^{\circ} \mathrm{C}$ for $2 \mathrm{~h}$. The cDNA was purified on MinElute columns and eluted from the column with $10 \mu \mathrm{l}$ elution buffer and dried for $15 \mathrm{~min}$ using Speed-Vac. Finally, $5 \mu \mathrm{l}$ of $2 \mathrm{X}$ coupling buffer and $5 \mu \mathrm{C} \mathrm{Cy} 3$ and Cy 5 dye were mixed into control and experimental cDNAs, respectively, and incubated in dark at room temperature for $1 \mathrm{~h}$. Following incubation, the labeled cDNA was purified on a MinElute column and eluted with $10 \mu \mathrm{l}$ of elution buffer.

Gene expression analysis. Mouse oligonucleotide glass arrays were procured from the NCI microarray facility, Frederick, MD, USA. These high-quality oligonucleotide arrays were designated Mm-MEEBO-v1.3px, with each slide having 48 blocks containing 28 rows and 28 columns each. Each slide had 36,960 oligonucleotide spots with a spacing of $155 \mu \mathrm{m}$. Arrays were prehybridized with $40 \mu$ prehybridization buffer (5X SSC, $1 \%$ BSA and $0.1 \%$ SDS) under a coverslip for $1 \mathrm{~h}$ at $42{ }^{\circ} \mathrm{C}$. The slides were then washed with deionized water and isopropanol (each wash $2 \mathrm{~min}$ ), spin-dried and kept at room temperature.

For hybridization, the $\mathrm{Cy} 3$ and $\mathrm{Cy} 5$ labeled cDNA were combined together and mixed with $1 \mu \mathrm{L}[10 \mu \mathrm{g}]$ COT-1 DNA, preheated at $100^{\circ} \mathrm{C}$ for $1 \mathrm{~min}$ to denature the target and cooled on ice for $2 \mathrm{~min}$. This mixture was added to $20 \mu \mathrm{l}$ of $2 \mathrm{X}$ F-hybridization buffer ( $50 \%$ formamide, 10X SSC, $0.2 \%$ SDS) and warmed to $42{ }^{\circ} \mathrm{C}$. The total cDNA probe $(40 \mu \mathrm{l})$ was added to the prehybridized array and covered with a coverslip. The slides were placed in hybridization chambers and incubated at $42{ }^{\circ} \mathrm{C}$ overnight $(12-16 \mathrm{~h})$. Following hybridization, the slides were washed for $2 \mathrm{~min}$ each in $2 \mathrm{X} \mathrm{SSC}$ and $0.1 \%$ SDS, $1 \mathrm{X}$ SSC and $0.2 \mathrm{X} \mathrm{SSC}$ and spin-dried.

Microarray slides were scanned in both $\mathrm{Cy} 3(532 \mathrm{~nm})$ and $\mathrm{Cy} 5$ $(635 \mathrm{~nm})$ channels using an Axon GenePix 4000B scanner (Axon Instruments, Foster City, CA, USA) with a $10 \mu \mathrm{M}$ resolution. Scanned 
microarray images were exported as TIFF files to GenePix Pro 3.0 software for image analysis. For data analysis, data files (in gpr format) and images (in jpeg format) were imported into the microarray database (mAdb), and analyzed by software tools provided by NCBI.

Quantitative real-time PCR analysis. Gene expression was verified by real-time PCR, using the DNA Engine Opticon ${ }^{\circledR} 2$ Real-Time PCR Detection System (MJ-Research/Bio Rad Laboratories, Hercules, CA, USA) in combination with primer sequences outlined in Table 1. Two micrograms of total RNA from each sample was used to synthesize first strand cDNA in a $20 \mu$ reaction mixture by using SuperScript II reverse transcriptase enzyme and random primers. Twenty nanogram of cDNA was utilized for the PCR reaction, using $\mathrm{iQ}^{\mathrm{TM}}$ SYBR green supermix and $500 \mathrm{nM}$ of each primer, under the following conditions: initial denaturation for $5 \mathrm{~min}$ at $95^{\circ} \mathrm{C}$, followed by 40 cycles consisting of $20 \mathrm{~s}$ at $94^{\circ} \mathrm{C}$, $20 \mathrm{~s}$ at $55^{\circ} \mathrm{C}$ and $30 \mathrm{~s}$ at $72{ }^{\circ} \mathrm{C}$. Amplifying known amounts of a PCR- product generated a standard curve at the same time as the samples. The expression of various mRNAs in each sample was normalized to the expression of $18 \mathrm{~S}$ rRNA.

\section{Results}

\section{Analysis of plasma proteins}

Many proteins are synthesized in liver and transported to the plasma, and as we had shown previously the importance of selenoproteins in liver function [14], the plasma protein profiles of $\Delta T r s p$ and wild type mice were examined. Equal amounts of plasma proteins from both mouse

Table 1

Primers used for real-time PCR

\begin{tabular}{|c|c|c|}
\hline Gene & Forward sequence & Reverse sequence \\
\hline Apoe & 5'-GAGGAACAGACCCAGCAAAT-3' & 5'-GCCACAGAGGCCTGTATCTT-3' \\
\hline Cyb5r3 & 5'-CCCGACATCAAGTACCCTCT-3' & 5'-GCCATCGATCCTAGTCGAG-3' \\
\hline Dhcr24 & 5'-TGCGAGTCGGAAAGTACAAG-3' & 5'-TGGAGTTCAGCAAAGCTGTC-3' \\
\hline$L d l r$ & 5'-TGGCCATCTATGAGGACAAA-3' & 5'-GTGTGACCTTGTGGAACAGG-3' \\
\hline Pctp & 5'-TGGCATACTGGGAAGTGAAG-3' & 5'-GACTTCTCGGGAAACTGAGG-3' \\
\hline Pmok & 5'-AGGCTGAAGAGCAGACTTGG-3' & 5'-CATGTCCCTCCGATAGGTCT-3' \\
\hline
\end{tabular}

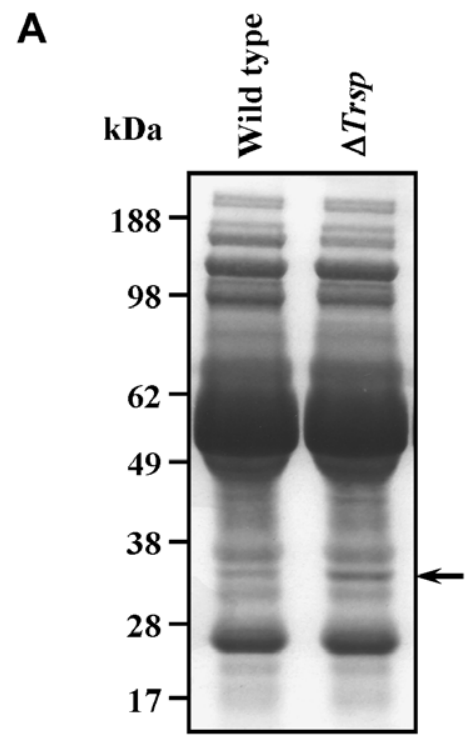

B 1 MKALWAVLLV TLLTGCLAEG EPEVTDQLEW QSNQPWEQAL NRFWDYLRWV

51 OTLSDQVQEE LQSSQVTQEL TALMEDTMTE VKAYKKELEE QLGPVAEETR

101 ARLGKEVQAA QARLGADMED LRNRLGQYRN EVHTMLGQST EEIRARLSTH

151 LRKMRKRLMR DAEDLQKRLA VYKAGAREGA ERGVSAIRER LGPLVEQGRQ

201 RTANLGAGAA QPLRDRAQAF GDRIRGRLEE VGNQARDRLE EVREHMEEVR

251 SKMEEQTOQI RLQAEIFQAR LKGWFEPIVE DMHRQWANLM EKIQASVATN

301 PIITPVAQEN Q

Fig. 1. Analysis of plasma proteins in wild type and $\Delta \operatorname{Tr} s p$ mice. (A) Plasma proteins from wild type and $\Delta \operatorname{Tr} s p$ mice were electrophoresed and stained with Coomassie blue. The elevated protein $(\sim 35 \mathrm{kDa})$ in $\Delta T r s p$ mice is indicated by an arrow. (B) Mouse ApoE sequence. Peptides detected by MS/MS analysis are underlined and shown in bold. 
lines were electrophoresed on polyacrylamide gels and stained with Coomassie blue. Staining revealed elevated levels of a protein at $\sim 35 \mathrm{kDa}$ in the plasma of $\Delta T r s p$ mice (Fig. 1A). The corresponding band was excised from the gel and protein identity determined by tandem mass spectrometry sequencing. This procedure revealed that the $35 \mathrm{kDa}$ protein is ApoE (Fig. 1B).

\section{ApoE protein and $m R N A$ levels in knockout mice}

To verify that ApoE levels were increased in plasma of $\Delta T r s p$ mice, equal amounts of plasma protein from both male and female wild type and $\Delta T r s p$ mice were electrophoresed and stained with Coomassie brilliant blue (Fig. 2A). Separately, the samples were examined in immunoblot assays using polyclonal anti-ApoE antibodies (Fig. 2A, lower panel). Increased ApoE was detected in both male and female $\Delta T r s p$ mice compared to their corresponding wild type counterparts. In addition, real-time PCR revealed a 1.4-fold increase in the levels of Apoe mRNA in the liver of $\Delta T r s p$ mice (Fig. 2B). Interestingly, Apoe mRNA levels were also significantly higher $(\sim 3.75-$ fold) in kidneys of $\Delta \operatorname{Tr} s p$ mice as compared to the wild type mice.
Analysis of cholesterol levels and genes involved in cholesterol biosynthesis

Cholesterol levels in plasma were examined in male and female wild type and $\Delta \operatorname{Tr} s p$ mice (Fig. $3 \mathrm{~A}$ ). The elevated level of ApoE was also reflected in plasma lipids with an increase in plasma cholesterol levels of $\Delta \operatorname{Tr} s p$ mice. Total plasma cholesterol was increased by $38.9 \%$ in $\Delta \operatorname{Tr} s p$ males and $35.5 \%$ in $\Delta \operatorname{Trsp}$ females. We further focused on male mice as they had a lower mean lifespan than their female counterparts [14].

The elevation of cholesterol in the plasma of $\Delta \operatorname{Trsp}$ mice prompted us to examine the expression profile of genes associated with cholesterol biosynthesis. Comparative analyses of gene expression using microarrays revealed altered expression of genes involved in cholesterol biosynthesis, metabolism and transport (Fig. 3B). Genes displaying a change of twofold or more were placed in a tabular form. The loss of Trsp in liver was associated with an increased expression of several genes involved in cholesterol biosynthesis (e.g., Cyb5r3, Dhcr24, Ebp, and Pmvk) and a decreased expression of genes involved in cholesterol metabolism or transport (e.g., Ldlr, Pctp, Star, and Stard3). A quantitative analysis of these genes confirmed
A
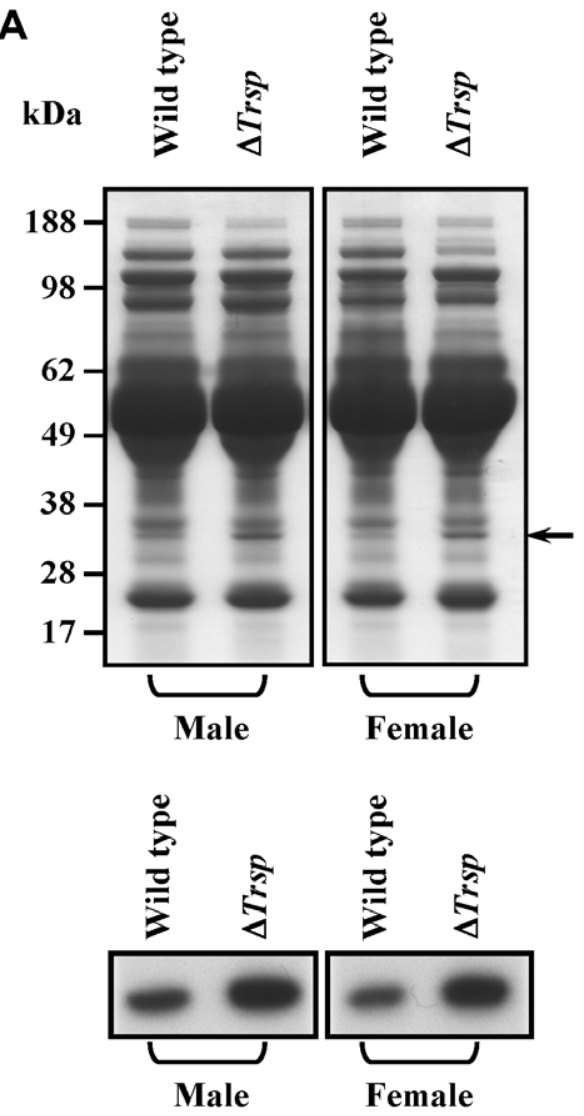

B

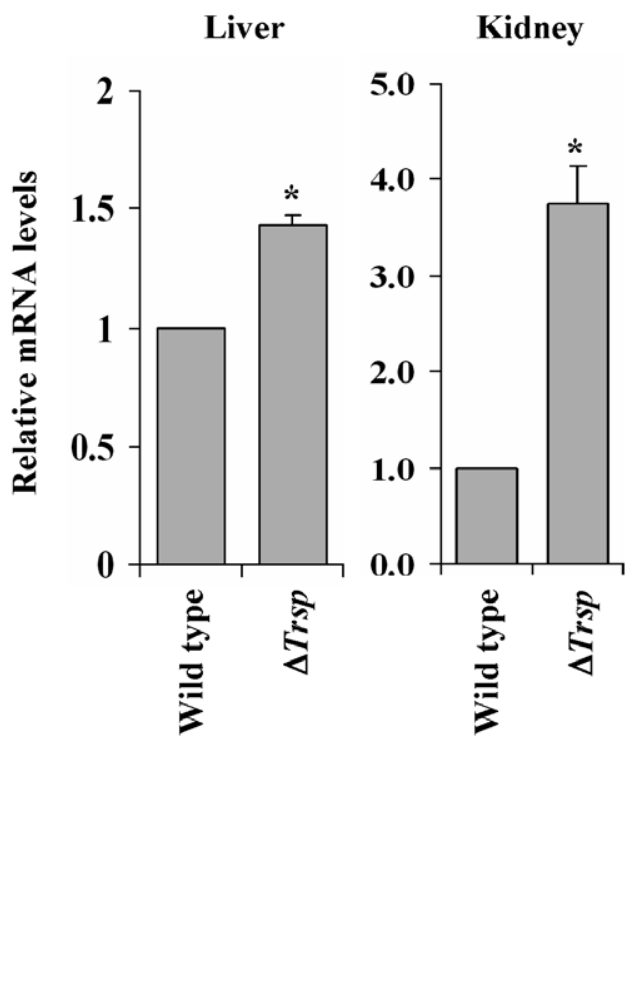

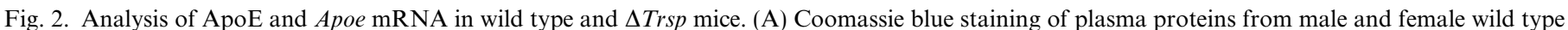

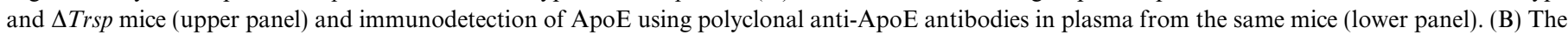

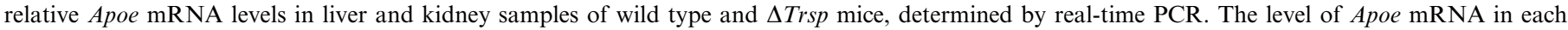

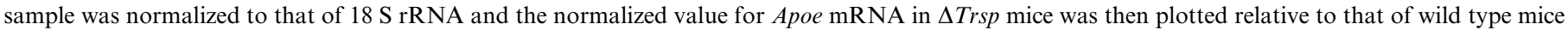

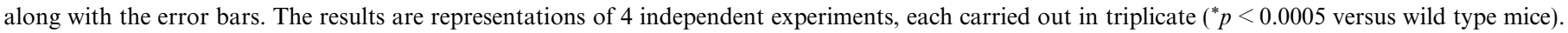


A

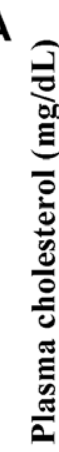

Female

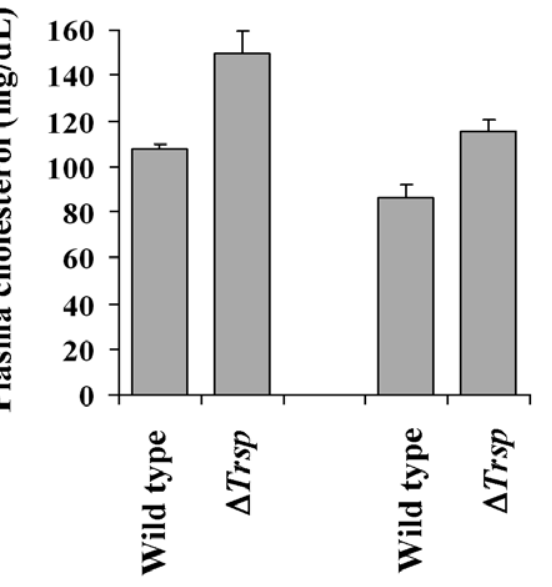

B

\begin{tabular}{|c|c|c|c|c|}
\hline UNIGENE & GENE DESCRIPTION & FUNCTION & $\triangle$ FOLD & SE \\
\hline \multicolumn{5}{|c|}{ Cholesterol Biosynthesis } \\
\hline Mm. 22560 & cytochrome b5 reductase 3 (Cyb5r3) & $\begin{array}{l}\text { cholesterol } \\
\text { biosynthesis }\end{array}$ & $\uparrow 9.92$ & 0.40 \\
\hline Mm.27183 & $\begin{array}{l}\text { phenylalkylamine } \mathrm{Ca} 2+\text { antagonist } \\
\text { (emopamil) binding protein }(E b p)\end{array}$ & $\begin{array}{l}\text { cholesterol } \\
\text { biosynthesis }\end{array}$ & $\uparrow \mathbf{6 . 4 2}$ & 0.46 \\
\hline Mm. 133370 & $\begin{array}{l}\text { 24-dehydrocholesterol reductase } \\
\text { (Dhcr 24) }\end{array}$ & $\begin{array}{l}\text { cholesterol } \\
\text { biosynthesis }\end{array}$ & $\uparrow \mathbf{3 . 3 2}$ & 0.61 \\
\hline Mm. 34242 & phosphomevalonate kinase $(P m v k)$ & $\begin{array}{l}\text { cholesterol } \\
\text { biosynthesis }\end{array}$ & $\uparrow 3.29$ & 0.02 \\
\hline \multicolumn{5}{|c|}{ Cholesterol Metabolism/Transport } \\
\hline Mm.293314 & $\begin{array}{l}\text { Steroidogenic acute regulatory } \\
\text { protein (Star) }\end{array}$ & $\begin{array}{l}\text { cholesterol } \\
\text { transport }\end{array}$ & $\downarrow 3.31$ & 0.11 \\
\hline Mm.5062 & $\begin{array}{l}\text { phosphatidylcholine transfer protein } \\
(P c t p)\end{array}$ & $\begin{array}{l}\text { cholesterol } \\
\text { metabolism }\end{array}$ & $\downarrow 2.97$ & 0.21 \\
\hline Mm.265546 & $\begin{array}{l}\text { START domain containing } 3 \\
(\text { Stard3) }\end{array}$ & $\begin{array}{l}\text { cholesterol } \\
\text { transport }\end{array}$ & $\downarrow 2.93$ & 0.25 \\
\hline Mm.3213 & $\begin{array}{l}\text { low density lipoprotein receptor } \\
(L d l r)\end{array}$ & $\begin{array}{l}\text { cholesterol } \\
\text { metabolism }\end{array}$ & $\downarrow 2.62$ & 0.06 \\
\hline
\end{tabular}

C

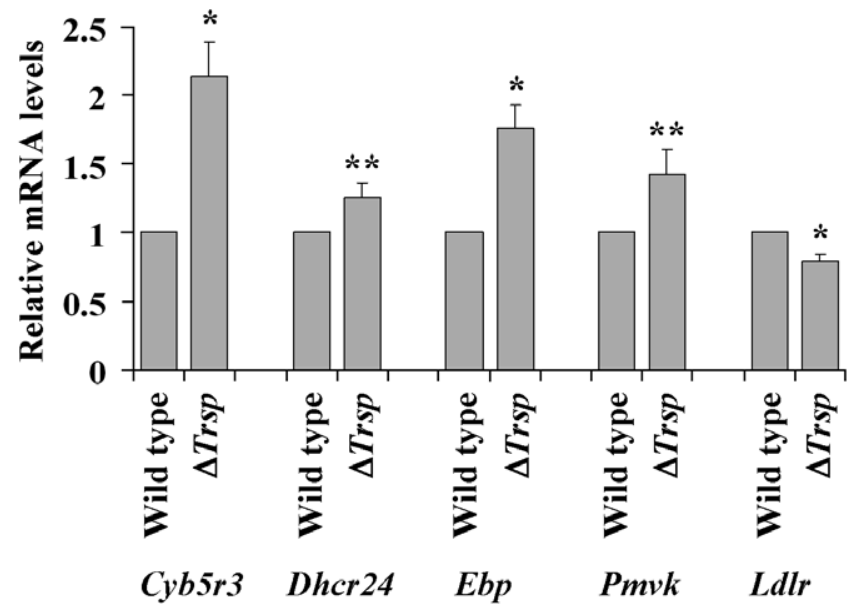

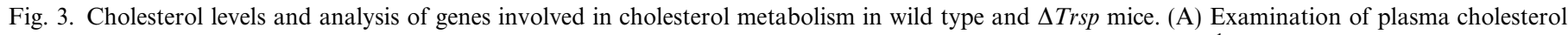

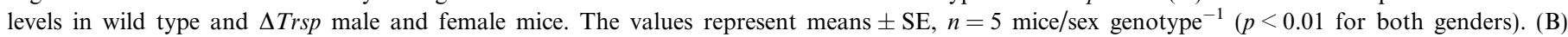

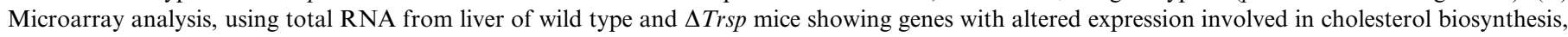

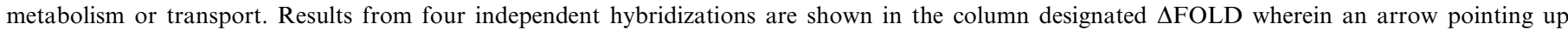

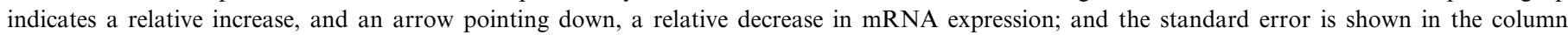

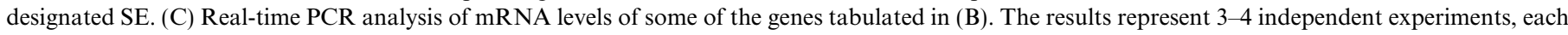
carried out in triplicate and shown along with the error bars $\left({ }^{*} p<0.005 ;{ }^{* *} p<0.1\right)$.

the microarray data for $C y b 5 r 3, D h c r 24, E b p, P m v k$, and Ldlr (Fig. 3C). The transcript levels of Pctp, Star, and Stard3 were too low to be detected under these experimental conditions and were not further examined.

\section{Analysis of ApoE levels and cholesterol levels in selenoprotein replacement mice}

To assess whether the elevation in ApoE and cholesterol levels was due to altered expression of housekeeping (e.g., TR1 and GPX4) or stress-related (e.g., GPX1 and SELT) selenoproteins, the plasma protein profiles of wild type and $\Delta T r s p$ mice were compared to the corresponding levels in $A 34$ and $G 37$ transgenic mice, which are known to express the former class of selenoproteins, but express the latter class poorly [14]. Equal amounts of plasma proteins from each mouse line were electrophoresed and stained with Coomassie brilliant blue (Fig. 4A). Western blot analysis detected ApoE levels in these mice and we found that $A 34$ and $G 37$ mice had normal levels of ApoE (Fig. 4A, lower panel).
Plasma lipid analysis showed that although the levels of cholesterol were elevated in $\Delta \operatorname{Tr} s p$ mice with respect to wild type mice, they were virtually identical in wild type and the A34 and G37 mice (Fig. 4B). Furthermore, expression of genes associated with cholesterol biosynthesis was restored in selenoprotein replacement mice and was more in line with that in wild type mice (data not shown).

\section{Discussion}

Selenoproteins are critical for proper liver function as their loss in this organ leads to severe necrosis and hepatocellular degeneration [14]. This observation suggested that the absence of selenoproteins in liver may influence the function of other proteins. To examine whether the levels of secreted proteins are altered in the mouse model of hepatic selenoprotein deficiency, we compared the levels of major plasma proteins from $\Delta T r s p$ and wild type mice and observed an increase in a $\sim 35 \mathrm{kDa}$ protein in liver knockout mice. Microsequencing and western blotting identified this protein as ApoE. The increase in ApoE 
A
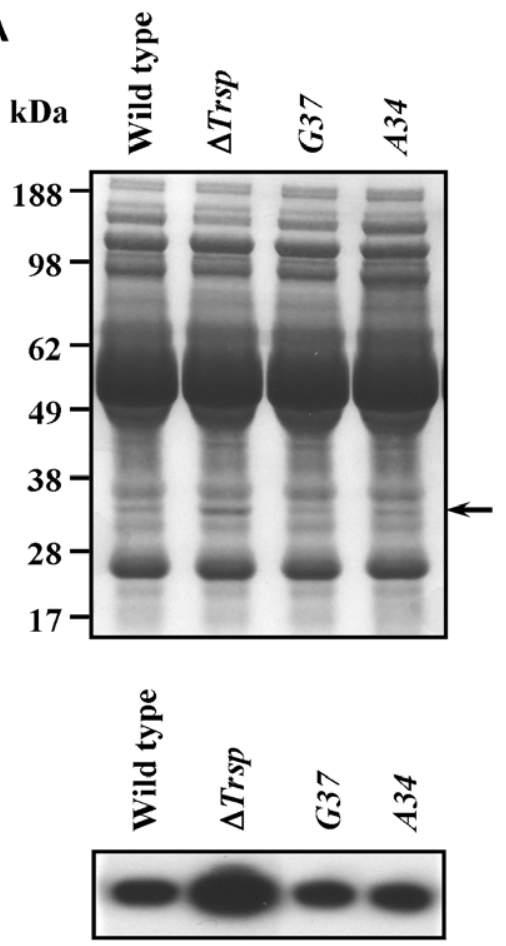

B

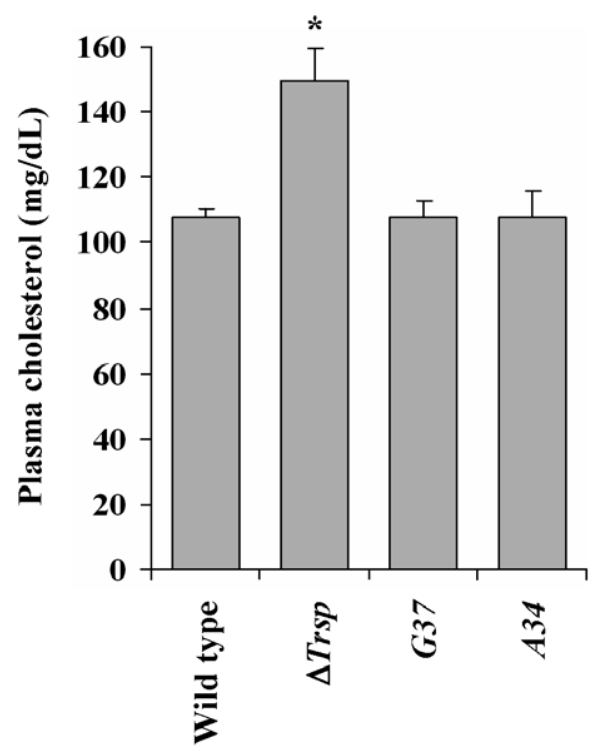

Fig. 4. ApoE and cholesterol levels in $A 34$ and $G 37$ mice. ApoE was assessed by Western blotting and cholesterol levels were measured in plasma lipids of wild type, $\Delta \operatorname{Tr} s p, A 34$, and $G 37$ mice. (A) Coomassie blue staining of plasma proteins from wild type, $\Delta T r s p, A 34$, and $G 37$ male mice (upper panel) and western blotting carried out using polyclonal anti-ApoE antibodies (lower panel). (B) Plasma cholesterol levels. Values represent means $\pm \mathrm{SE}, n=5$ mice/ genotype for wild type and $\Delta \operatorname{Trsp}$ mice and $n=4$ mice/genotype for $A 34$ and $G 37$ mice $\left({ }^{*} p<0.01\right)$.

was accompanied by an increase in cholesterol levels in the plasma of $\Delta \operatorname{Trsp}$ mice, which did not appear to be gender specific. A comparative gene expression analysis in livers of $\Delta T r s p$ and wild type mice revealed an enhanced expression of genes involved in cholesterol biosynthesis and a decreased expression of genes involved in cholesterol metabolism and transport in $\Delta T r s p$ mice. The Apoe mRNA levels were also significantly higher in the kidney of $\Delta T r s p$ mice as compared with the kidney from wild type mice. Earlier reports suggested that Apoe is synthesized in both liver and kidney [15], and the increased mRNA levels observed in kidney could also account for elevated levels of the protein in plasma.

It was previously reported that selenium deficiency results in an increased plasma cholesterol concentration $[16,17]$ along with an increase in ApoE levels [18]. It was speculated that this increase was related to an increase in the HDL1 fraction [18] which is rich in ApoE. The present study analyzed the effects of the targeted removal of Trsp in liver of mice fed a selenium sufficient diet. Interestingly, the findings of increased cholesterol and elevated levels of ApoE in the $\Delta T r s p$ mice are similar to those reported earlier in rats maintained on selenium deficient diets [19]. Thus, these observations could be attributed to the absence of selenoproteins in liver, even though our mice were fed selenium sufficient diets. Since stress-related selenoproteins are more susceptible to selenium status than housekeeping selenoproteins, one might expect that the former subclass of selenoproteins is responsible for the observed effect. To test this possibility we examined levels of ApoE and cholesterol in the $A 34$ and $G 37$ transgenic mice. The housekeeping, but not stress-related selenoprotein population was replaced in these transgenic mice, yet the levels of ApoE and plasma cholesterol were restored to those observed in the corresponding wild type mice. Thus, the observed changes in ApoE and cholesterol levels and their restoration in mice in which housekeeping selenoproteins were expressed, suggests that stress-related selenoproteins could not account for this effect.

Several selenoprotein mRNAs were restored in $A 34$ and G37 transgenic mice, such as Diol, Selk, Sepp1, and Sep15 [13], while others like $T R 1$ and $T R 3$ were restored partially. Although mRNA levels might not necessarily match protein expression levels, our data suggest that some of these or other restored selenoproteins are responsible for the role of selenium in ApoE and cholesterol metabolism.

Earlier studies have suggested a role of selenium [20] and/or selenoproteins in cardiovascular disorders [21] and reports indicate that cholesterol levels increase in selenium deficient animals compared to adequate selenium fed animals [22]. Our studies suggest that these effects are most likely executed through a select group of selenoproteins as our mouse models have shown that the loss of Sec tRNA $^{[\mathrm{Ser}] \mathrm{Sec}}$ elicits similar conditions, even under selenium sufficient diets. It is of interest to note that the selenium content of liver from $\Delta T r s p$ and the mutant Trsp transgenic 
mice are similar and only about $30 \%$ of wild type. This observation provides further evidence that the selenium effect is mediated through (a) housekeeping selenoprotein(s) providing evidence for a novel role of this subclass in human health through modulation of lipoprotein and cholesterol metabolism.

\section{Acknowledgments}

This research was supported by the Intramural Research Program of the National Institutes of Health, National Cancer Institute, Center for Cancer Research and by NIH Grants to V.N.G.

\section{References}

[1] P.D. Whanger, Selenium and its relationship to cancer: an update dagger, Br. J. Nutr. 91 (2004) 11-28.

[2] M.P. Rayman, The importance of selenium to human health, Lancet 356 (2000) 233-241.

[3] D.L. Hatfield (Ed.), Selenium: Its Molecular Biology and Role in Human Health, Kluwer Academic Publishers, Norwell, MA, 2001.

[4] D.L. Hatfield, V.N. Gladyshev, How selenium has altered our understanding of the genetic code, Mol. Cell Biol. 22 (2002) 35653576.

[5] G.V. Kryukov, S. Castellano, S.V. Novoselov, A.V. Lobanov, O. Zehtab, R. Guigo, V.N. Gladyshev, Characterization of mammalian selenoproteomes, Science 300 (2003) 1439-1443.

[6] J. Kohrl, R. Brigelius-Flohe, A. Bock, R. Gartner, O. Meyer, L. Flohe, Selenium in biology: facts and medical perspectives, Biol. Chem. 381 (2000) 849-864.

[7] I.S. Choi, A.M. Diamond, P.F. Crain, J.D. Kolker, J.A. McCloskey, D.L. Hatfield, Reconstitution of the biosynthetic pathway of selenocysteine tRNAs in Xenopus oocytes, Biochemistry 33 (1994) 601-605.

[8] L.K. Kim, T. Matsufuji, S. Matsufuji, B.A. Carlson, S.S. Kim, D.L. Hatfield, B.J. Lee, Methylation of the ribosyl moiety at position 34 of selenocysteine tRNA[Ser]Sec is governed by both primary and tertiary structure, RNA 6 (2000) 1306-1315.

[9] D. Hatfield, B.J. Lee, L. Hampton, A.M. Diamond, Selenium induces changes in the selenocysteine tRNA[Ser]Sec population in mammalian cells, Nucleic Acids Res. 19 (1991) 939-943.

[10] M.R. Bosl, K. Takaku, M. Oshima, S. Nishimura, M.M. Taketo, Early embryonic lethality caused by targeted disruption of the mouse selenocysteine tRNA gene (Trsp), Proc. Natl. Acad. Sci. USA 94 (1997) 5531-5534.
[11] E. Kumaraswamy, B.A. Carlson, F. Morgan, K. Miyoshi, G.W. Robinson, D. Su, S. Wang, E. Southon, L. Tessarollo, B.J. Lee, V.N. Gladyshev, L. Hennighausen, D.L. Hatfield, Selective removal of the selenocysteine tRNA [Ser]Sec gene (Trsp) in mouse mammary epithelium, Mol. Cell Biol. 23 (2003) 1477-1488.

[12] B.A. Carlson, X.M. Xu, V.N. Gladyshev, D.L. Hatfield, Selective rescue of selenoprotein expression in mice lacking a highly specialized methyl group in selenocysteine tRNA, J. Biol. Chem. 280 (2005) 5542-5548.

[13] B.A. Carlson, M.E. Moustafa, A. Sengupta, U. Schweizer, R. Shrimali, M. Rao, N. Zhong, S. Wang, L. Feigenbaum, B.J. Lee, V.N. Gladyshev, D.L. Hatfield, Selective restoration of the selenoprotein population in a mouse hepatocyte selenoproteinless background with different mutant selenocysteine tRNAs lacking Um34, J. Biol. Chem. 282 (2007) 32591-32602.

[14] B.A. Carlson, S.V. Novoselov, E. Kumaraswamy, B.J. Lee, M.R. Anver, V.N. Gladyshev, D.L. Hatfield, Specific excision of the selenocysteine tRNA[Ser]Sec (Trsp) gene in mouse liver demonstrates an essential role of selenoproteins in liver function, J. Biol. Chem. 279 (2004) 8011-8017.

[15] M.L. Blue, D.L. Williams, S. Zucker, S.A. Khan, C.B. Blum, Apolipoprotein E synthesis in human kidney, adrenal gland, and liver, Proc. Natl. Acad. Sci. USA 80 (1983) 283-287.

[16] W.L. Stone, M.E. Stewart, C. Nicholas, S. Pavuluri, Effects of dietary selenium and vitamin $\mathrm{E}$ on plasma lipoprotein cholesterol levels in male rats, Ann. Nutr. Metab. 30 (1986) 94-103.

[17] W.L. Stone, R.L. Scott, E.M. Stewart, A. Kheshti, Lipoprotein alterations in the spontaneously hypertensive rat fed diets deficient in selenium and vitamin E, Proc. Soc. Exp. Biol. Med. 206 (1994) 130 137.

[18] A. Mazur, F. Nassir, E. Gueux, C. Moundras, J. Bellanger, P. Grolier, E. Rock, Y. Rayssiguier, Diets deficient in selenium and vitamin $\mathrm{E}$ affect plasma lipoprotein and apolipoprotein concentrations in the rat, Br. J. Nutr. 76 (1996) 899-907.

[19] S. Dhingra, M.P. Bansal, Attenuation of LDL receptor gene expression by selenium deficiency during hypercholesterolemia, Mol. Cell Biochem. 282 (2006) 75-82.

[20] J. Wojcicki, L. Rozewicka, B. Barcew-Wiszniewska, L. Samochowiec, S. Juzwiak, D. Kadlubowska, S. Tustanowski, Z. Juzyszyn, Effect of selenium and vitamin $\mathrm{E}$ on the development of experimental atherosclerosis in rabbits, Atherosclerosis 87 (1991) 9-16.

[21] R.K. Shrimali, J.A. Weaver, G.F. Miller, M.F. Starost, B.A. Carlson, S.V. Novoselov, E. Kumaraswamy, V.N. Gladyshev, D.L. Hatfield, Selenoprotein expression is essential in endothelial cell development and cardiac muscle function, Neuromuscul. Disord. 17 (2007) 135-142.

[22] S. Dhingra, M.P. Bansal, Hypercholesterolemia and apolipoprotein B expression: regulation by selenium status, Lipids Health Dis. 4 (2005) 28. 